\title{
Diel vertical migration of squid in the warm core ring and cold water masses in the transition region of the western North Pacific
}

\author{
Hikaru Watanabe ${ }^{1,5, *}$, Tsunemi Kubodera ${ }^{2}$, Masatoshi Moku ${ }^{3}$, Kouichi Kawaguchi ${ }^{4}$ \\ ${ }^{1}$ National Research Institute of Far Seas Fisheries, 5-7-1 Orido Shimizu, Shizuoka 424-8633, Japan \\ ${ }^{2}$ National Science Museum, 3-23-1 Hyakunin-cho Shinjuku, Tokyo 169-0073, Japan \\ ${ }^{3}$ National Fisheries University, 2-7-1 Nagata-Honmachi, Shimonoseki, Yamaguchi 759-6595, Japan \\ ${ }^{4}$ Ocean Research Institute, University of Tokyo, 1-15-1 Minamidai, Nakano, Tokyo 164-8639, Japan \\ ${ }^{5}$ Present address: National Research Institute of Far Seas Fisheries, 2-12-4 Fukuura Kanazawa Yokohama, \\ Kanagawa 236-8648, Japan
}

\begin{abstract}
We examined the diel vertical migration of squid (dorsal mantle length 21 to $490 \mathrm{~mm}$ ) in warm core ring (WCR) and cold water mass (CW) areas in the transition region of the western North Pacific. A total of 28 squid species belonging to 23 genera, 2 octopus species from 2 genera, and 1 vampyrmorph Vampyroteuthis infernalis were captured from depths of 20 to $700 \mathrm{~m}$ by day and night sampling using a commercial otter trawl. Three patterns of diel vertical migration were recognized for 11 of the squid species. (1) Migrant, in which day and night habitats are clearly separated with peak abundance deeper than $300 \mathrm{~m}$ during the day and shallower than $300 \mathrm{~m}$ at night: Gonatopsis borealis, Gonatus berryi, Gonatus onyx, Eucleoteuthis luminosa, Onychoteuthis banksii, Enoploteuthis chunii, and Watasenia scintillans. (2) Semi-migrant, in which part of the population migrates to the upper $100 \mathrm{~m}$ at night from its daytime habitat of 500 to $600 \mathrm{~m}$, while the remainder of the population mainly remains in the daytime habitat: $O$. borealijaponica. (3) Non-migrant, in which the habitat is consistently distributed below $400 \mathrm{~m}$ : Histioteuthis dofleini, Belonella borealis, and H. inermis. Horizontally, E. luminosa, E. chunii, and H. inermis were restricted to the WCR, while other species were distributed in both the WCR and CW areas in the transition region. Among the vertically migratory and semi-migratory species, nighttime distribution depth was similar between WCR and CW for O. banksii, but was deepened by upper layers of warm subtropical waters in the WCR for G. borealis, G. berryi, W. scintillans, and O. borealijaponica. We also examined day-night habitat temperature ranges for these 11 species.
\end{abstract}

KEY WORDS: Squid $\cdot$ Diel vertical migration $\cdot$ Water temperature $\cdot$ Warm core ring $\cdot$ Cold water mass · Transition region · Western North Pacific

\section{INTRODUCTION}

Squid are one of the main component animals in oceanic ecosystems. About 50 species are distributed in the transition waters of the North Pacific (Nesis 1982, Sweeney et al. 1992, Okutani 2005). In these waters, micronektonic squid are eaten by various predators such as albacore, Pacific pomfret, and neon flying squid (Pearcy 1991, Watanabe et al. 2003, $2004 \mathrm{a}$,b), while those larger than 100 to $150 \mathrm{~mm}$ in dorsal mantle length (DML) are eaten by larger predators, such as swordfish, blue shark, northern fur seals,
Baird's beaked whales, Dall's porpoise, and sperm whales (Okutani et al. 1976, Pearcy 1991, Ohizumi et al. 2000, 2003, Mori et al. 2001). Therefore, squid are thought to play an important role in oceanic food webs, occupying mainly tertiary to quaternary trophic levels. Species in the region are categorized into 3 types based on the zoogeographical distribution patterns of adults, mainly during spring and summer, i.e. subarctic and transition water species, subtropical species, and slope water species (Nesis 1982, Voss et al. 1998, Tsuchiya 2000, Okutani 2005). Considerable knowledge of their zoogeography in the transitional and sub- 
arctic North Pacific has been accumulated (Clarke 1966, Nesis 1982, Kubodera et al. 1983, Sweeney et al. 1992, Okutani 2002, 2005). The diel vertical migrations (DVM) of their larvae and small juveniles (mostly smaller than $30 \mathrm{~mm}$ DML) have also been studied in the eastern North Pacific off Oregon and southern California, and in the central North Pacific around Hawaii (Roper \& Young 1975, Pearcy et al. 1977). However, knowledge about larger adults is restricted to only a few species, such as neon flying squid (400 to $500 \mathrm{~mm}$ DML) and diamondback squid (500 $\mathrm{mm}$ DML) in the eastern and western North Pacific, the day-night vertical movements of which have been monitored by ultrasonic telemetry (Iizuka 1990, Nakamura 1991, Tanaka 2001). Knowledge of vertical distribution patterns is essential when conducting quantitative sampling of squid to evaluate their biomass. Here, we describe DVM patterns of the 11 most abundant squid species in the transition waters of the western North Pacific, where the subtropical Kuroshio and subarctic Oyashio waters produce a complex environment affecting DVM patterns of various marine organisms.

\section{MATERIALS AND METHODS}

A total of 32 samples were taken from 2 fixed stations (Stn C: $40^{\circ} \mathrm{N}, 145^{\circ} \mathrm{E}$; Stn W: $39^{\circ} \mathrm{N}, 143^{\circ} 30^{\prime} \mathrm{E}$ ) within a circle 10 nautical miles in radius in the transition region. Samples were collected from 15 to 16 July 1996 at Stn C and from 29 to 30 July 1996 at Stn W by the commercial trawler 'Marusada-Maru' chartered by the Japan Marine Fishery Resources Research Center (Fig. 1). The trawl net was $103 \mathrm{~m}$ long, with a mouth opening of about $490 \mathrm{~m}^{2}$ and an $11 \mathrm{~m}$ cod end with $1.8 \times$ $1.8 \mathrm{~cm}$ mesh. The mesh size of the cod end was not fine enough to effectively collect juvenile cephalopods less than $20 \mathrm{~mm}$ in DML. Tows conducted between $1 \mathrm{~h}$ after sunrise and $1 \mathrm{~h}$ before sunset, and between $1 \mathrm{~h}$ after sunset and $1 \mathrm{~h}$ before sunrise, were considered daytime and nighttime samples, respectively. During the daytime, 1 or $2 \mathrm{~h}$ horizontal tows were made at 1.3 to $2.1 \mathrm{~m}$ $\mathrm{s}^{-1}$ ( 2.5 to 4 knots) in 5 layers at $100 \mathrm{~m}$ intervals between depths of 200 and $700 \mathrm{~m}$. The upper $200 \mathrm{~m}$ layer was sampled by an oblique tow. At night, 0.5 or $1 \mathrm{~h}$ tows

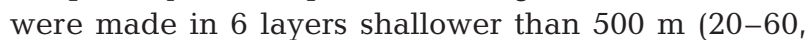
$60-100,100-200,200-300,300-400$, and $400-500 \mathrm{~m}$ ), and $1 \mathrm{~h}$ tows were made for the 500 to 600 and 600 to $700 \mathrm{~m}$ layers. Sampling in the upper $20 \mathrm{~m}$ was not possible because the otter boards did not function properly at this depth. Because the trawl was not equipped with opening-closing devices, we adopted the following procedures to reduce the contamination of the catch by shallower layers: when the net was cast, the ship stopped or slowed to around $1.0 \mathrm{~m} \mathrm{~s}^{-1}$ (2 knots) and the

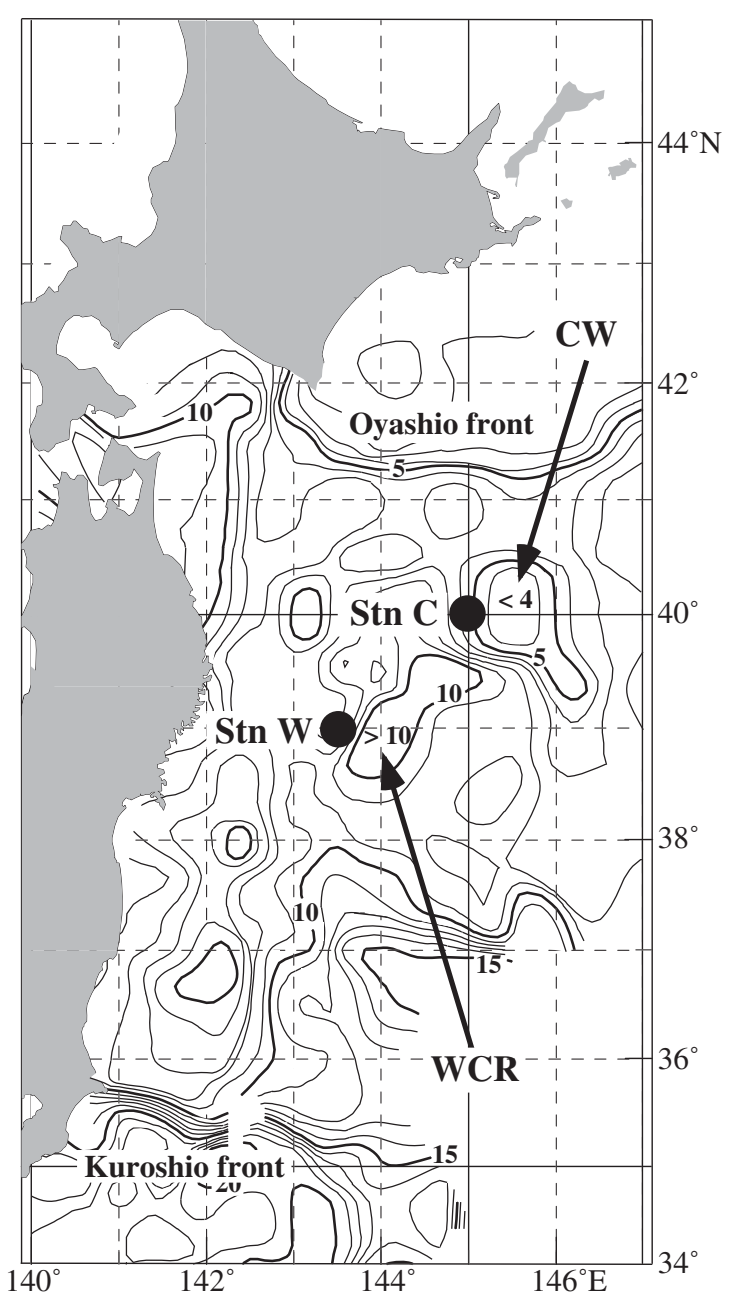

Fig. 1. Sampling locations and temperature field (in ${ }^{\circ} \mathrm{C}$ ) at $100 \mathrm{~m}$ depth (Tohoku National Fisheries Research Institute, www.myg.affrc.go.jp/kaijo/temp/data/199607_100.gif) in the transition and adjacent waters of the western North Pacific in July 1996. CW: cold water mass; WCR: warm core ring

wire was released rapidly to minimize the volume of water filtered by the net and the herding effect of the otter boards; during retrieval, the ship stopped or moved backwards so that the net was not being towed horizontally, and it was then hauled in vertically. Using this procedure, contamination by the upper layer was estimated to be less than $4 \%$ of the total catch (see 'Discussion'). The sampling depth and height of the net mouth were monitored with an acoustic recorder attached to the head rope of the trawl. A salinity-temperature-depth profile (STD), cast to a depth of $700 \mathrm{~m}$, was conducted at each station to determine the water mass sampled. We also referred to the temperature field at $100 \mathrm{~m}$ depth off northern Japan to determine the position of the Kuroshio and Oyashio fronts (Tohoku National Fisheries Research Institute, Fig. 1). The 
cephalopods were frozen at $-30^{\circ} \mathrm{C}$ aboard the ship. In the laboratory ashore, all cephalopods were identified to the lowest taxon possible, and the DML and body wet weight of each individual was measured. Catch in wet weight was converted to catch per $1 \mathrm{~h}$ tow for each sampling layer.

\section{RESULTS}

\section{Oceanographic conditions}

The temperature field at $100 \mathrm{~m}$ depth and the 2 sampling positions in the transition region between the Kuroshio and Oyashio fronts are shown in Fig. 1; Stn C was located on the periphery of the cold water mass (CW) that separated southward from the Oyashio front, while Stn W was located on the periphery of the warm core ring (WCR) dispatched from the Kuroshio front. The vertical temperature and salinity profiles at the 2 sampling stations were quite different, representing the typical characteristics of the Oyashio and Kuroshio-derived waters at Stns C and W, respectively (Kawai 1972, Fig. 2).

\section{Species composition}

Twenty-eight teuthoid squid species belonging to 23 genera, 2 octopus species, Haliphron atlanticus and Japetella diaphana, and 1 vampyromorph Vampyroteuthis infernalis were collected (Table 1). Most of the subarctic and transition water species, and 1 slope

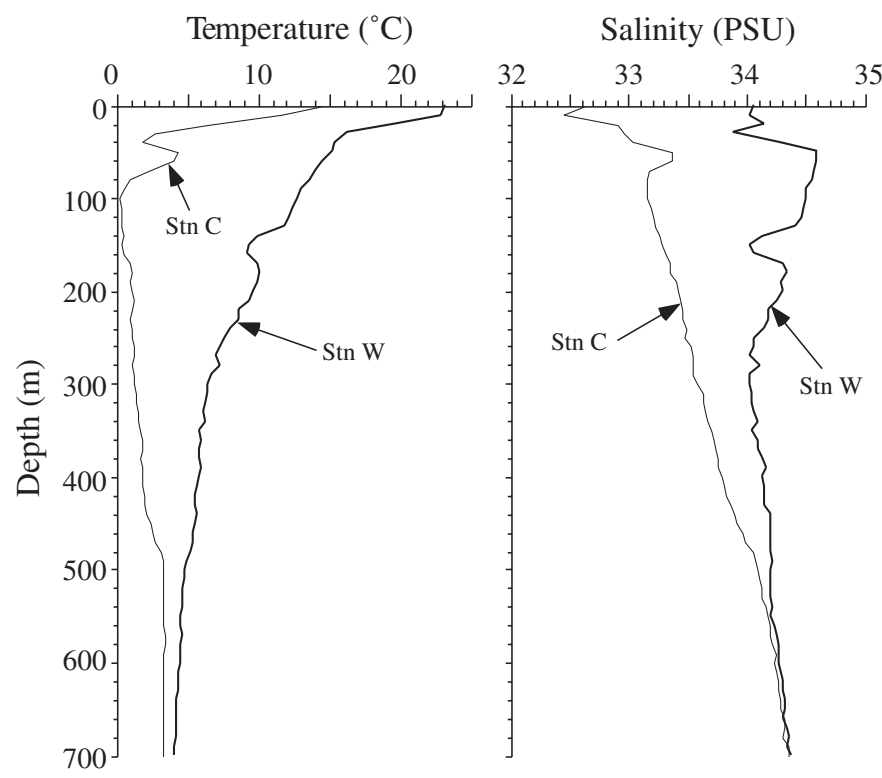

Fig. 2. Temperature and salinity profiles of the 2 sampling stations (Stn C and Stn W) water species, Watasenia scintillans, were captured at both stations; however, Abraliopsis felis was restricted to Stn C and Gonatus californiensis to Stn W. All subtropical species were collected at Stn W. Of these, Ommastrephes bartramii, Onychoteuthis banksii, and Mastigoteuthis glaukopis were also collected at Stn C. The DMLs of all 31 species were larger than $20 \mathrm{~mm}$, except for 1 Eogonatus tinro individual (15 mm), while the largest specimen was Galiteuthis phyllura (550 mm) captured at Stn W (Table 1).

\section{Diel vertical migrations of abundant species}

The DVM patterns of the 8 most common species (i.e. total catch $>30$ individuals, Table 1) are described below.

\section{Subarctic and transition water species}

Gonatopsis borealis. Vertical distribution: This species was mainly distributed in the 500 to 700 m layer in the daytime (Fig. 3a). At night, almost all of the population migrated to the 20 to $60 \mathrm{~m}$ layer at Stn C. In contrast, its nighttime distribution was restricted to depths in excess of $60 \mathrm{~m}$, with peak abundance in the 100 to $200 \mathrm{~m}$ layer at Stn W, probably because of the presence of warm waters in the upper layers (Figs. 2 \& 3a).

Temperature range: From 3 to $5^{\circ} \mathrm{C}$ during the day and 5 to $10^{\circ} \mathrm{C}$ at night (Figs. 2 \& 3a).

Gonatus berryi. Vertical distribution: This species occurred mainly between 500 and $700 \mathrm{~m}$ during the day (Fig. 3b). At night, it migrated to the 60 to $100 \mathrm{~m}$ layer at Stn C, but its distribution was restricted to below $200 \mathrm{~m}$ at Stn W, probably because of warm waters in the upper layers.

Temperature range: From 3 to $5^{\circ} \mathrm{C}$ during the day and 5 to $10^{\circ} \mathrm{C}$ at night (Figs. $2 \& 3 \mathrm{~b}$ ).

Onychoteuthis borealijaponica. Vertical distribution: This species was mainly distributed at depths of 500 to $600 \mathrm{~m}$ during the day, but showed a bimodal depth distribution at night, i.e. part of the population migrated to the upper 200 m layer, while the rest mostly remained in the daytime habitat (Fig. 3c). In the epipelagic layer at night, this species was mainly distributed in the 20 to $100 \mathrm{~m}$ layer at Stn C, and in the 100 to 200 m layer at Stn W, probably because of the warm upper layers.

Temperature range: The daytime habitat temperature was 3 to $5^{\circ} \mathrm{C}$; at night, part of the population migrated up to layers at 5 to $10^{\circ} \mathrm{C}$ (Figs. $2 \& 3 \mathrm{c}$ ).

Histioteuthis dofleini. Vertical distribution: This squid occurred mainly in the 500 to $700 \mathrm{~m}$ depth layer during both day and night, i.e. it was non-migrant (Fig. 3d). 
Temperature range: From 3 to $5^{\circ} \mathrm{C}$ during both day and night, i.e. stenothermal (Figs. 2 \& 3d).

Belonella borealis. Vertical distribution: This species showed no notable diel vertical migration, occurring at 500 to $700 \mathrm{~m}$ during the daytime and 400 to $700 \mathrm{~m}$ at night, i.e. non-migrant (Fig. 4a).

Temperature range: From 3 to $6^{\circ} \mathrm{C}$ (stenothermal; Figs. $2 \& 4 \mathrm{a})$.
Subtropical species

Eucleoteuthis luminosa. Vertical distribution: This squid was captured only at Stn W. The daytime habitat was mainly between 400 and $500 \mathrm{~m}$, and shifted up to 20 to $60 \mathrm{~m}$ at night (Fig. 4b).

Temperature range: From 4 to $6^{\circ} \mathrm{C}$ during the day and 15 to $20^{\circ} \mathrm{C}$ at night, i.e. eurythermal (Figs. $2 \& 4$ b).

Table 1. Species of cephalopods collected from 0 to $700 \mathrm{~m}$ depth in the cold water mass (Stn C) and warm core ring (Stn W) areas of the western transitional North Pacific in July 1996. -: species was not found at a sampling station

\begin{tabular}{|c|c|c|c|c|c|c|c|c|}
\hline \multirow[t]{2}{*}{ Species } & \multicolumn{3}{|c|}{$-\operatorname{Stn} \mathrm{C}$} & \multicolumn{3}{|c|}{$\longrightarrow$ Stn $\mathrm{W}$} & \multicolumn{2}{|c|}{ Total catch } \\
\hline & $\begin{array}{l}\text { Total catch } \\
\text { (kg wet wt) }\end{array}$ & $\begin{array}{l}\text { Abundance } \\
\text { (No. ind.) }\end{array}$ & $\begin{array}{l}\text { Size range } \\
\text { (mm DML) }\end{array}$ & $\begin{array}{r}\text { Total catch } \\
\text { (kg wet wt) }\end{array}$ & $\begin{array}{c}\text { Abundance } \\
\text { (No. ind.) }\end{array}$ & $\begin{array}{l}\text { Size range } \\
\text { (mm DML) }\end{array}$ & $\begin{array}{c}(\mathrm{kg} \\
\text { wet } \mathrm{wt})\end{array}$ & (No.) \\
\hline \multicolumn{9}{|l|}{ Subarctic and transition } \\
\hline \multicolumn{9}{|l|}{ Teuthoid squid } \\
\hline Histioteuthis dofleini & 3.2 & 10 & $65-156$ & 10.8 & 32 & $24-156$ & 14.0 & 42 \\
\hline Gonatopsis borealis & 5.8 & 22 & $43-253$ & 1.7 & 184 & $31-156$ & 7.5 & 206 \\
\hline Belonella borealis & 6.1 & 14 & $210-490$ & 1.2 & 26 & $171-355$ & 7.3 & 40 \\
\hline Onychoteuthis borealijaponica & 2.9 & 28 & $125-213$ & 0.3 & 24 & $42-87$ & 3.2 & 52 \\
\hline Gonatus berryi & 1.2 & 21 & $81-150$ & 1.2 & 66 & $34-147$ & 2.4 & 87 \\
\hline Chiroteuthis calyx & 1.8 & 5 & $112-255$ & 0.4 & 5 & $109-160$ & 2.2 & 10 \\
\hline Galiteuthis phyllura & 0.2 & 1 & 510 & 1.2 & 6 & $248-550$ & 1.4 & 7 \\
\hline Octopoteuthis deletron & 0.6 & 2 & $150-184$ & 0.5 & 1 & 231 & 1.1 & 3 \\
\hline Gonatus onyx & 0.2 & 10 & $52-77$ & 0.3 & 2 & $110-187$ & 0.5 & 12 \\
\hline Gonatus pyros & 0.1 & 3 & $77-100$ & 0.1 & 3 & $102-119$ & 0.2 & 6 \\
\hline Eogonatus tinro & 0.1 & 6 & $15-81$ & $<0.1$ & 1 & 61 & 0.1 & 7 \\
\hline Gonatus californiensis & - & - & - & 0.1 & 1 & 187 & 0.1 & 1 \\
\hline Abraliopsis felis & $<0.1$ & 4 & $45-52$ & - & - & - & $<0.1$ & 4 \\
\hline Gonatus spp. & 1.2 & 19 & $34-250$ & 0.3 & 14 & $62-178$ & 1.5 & 33 \\
\hline \multicolumn{9}{|l|}{ Subtropical } \\
\hline \multicolumn{9}{|l|}{ Teuthoid squid } \\
\hline Histioteuthis inermis & - & - & - & 3.8 & 11 & $49-152$ & 3.8 & 11 \\
\hline Eucleoteuthis luminosa & - & - & - & 2.7 & 35 & $92-161$ & 3.1 & 35 \\
\hline Ommastrephes bartramii & 0.5 & 1 & 245 & 0.8 & 6 & $168-178$ & 1.3 & 7 \\
\hline Onychoteuthis banksii & 0.2 & 30 & $39-73$ & 0.8 & 132 & $35-73$ & 1.0 & 162 \\
\hline Enoploteuthis chunii & - & - & - & 0.6 & 18 & $31-89$ & 0.6 & 18 \\
\hline Discoteuthis discus & - & - & - & 0.3 & 5 & $67-110$ & 0.3 & 5 \\
\hline Ancistrocheirus lesueuri & - & - & - & 0.3 & 1 & 182 & 0.3 & 1 \\
\hline Ctenopteryx siculus & - & - & - & 0.2 & 3 & $168-178$ & 0.2 & 3 \\
\hline Bathyteuthis abyssicola & - & - & - & 0.2 & 3 & $60-63$ & 0.2 & 3 \\
\hline Mastigoteuthis glaukopis & $<0.1$ & 3 & $65-80$ & $<0.1$ & 6 & $80-105$ & 0.1 & 9 \\
\hline Liocranchia reinhardti & - & - & - & 0.1 & 2 & $62-65$ & 0.1 & 2 \\
\hline Taningia danae & - & - & - & $<0.1$ & 6 & $32-57$ & $<0.1$ & 6 \\
\hline Moroteuthis loennbergi & - & - & - & $<0.1$ & 1 & 65 & $<0.1$ & 1 \\
\hline Sandalops melancholicus & - & - & - & $<0.1$ & 1 & 61 & $<0.1$ & 1 \\
\hline \multicolumn{9}{|l|}{ Octopod } \\
\hline Haliphron atlanticus & - & - & - & 0.7 & 8 & $35-55$ & 0.6 & 8 \\
\hline Japetella diaphana & - & - & - & 0.4 & 7 & $48-116$ & 0.4 & 7 \\
\hline \multicolumn{9}{|l|}{ Vampyromorph } \\
\hline Vampyroteuthis infernalis & - & - & - & 0.1 & 3 & $65-110$ & 0.1 & 3 \\
\hline \multicolumn{9}{|l|}{ Slope water } \\
\hline \multicolumn{9}{|l|}{ Teuthod squid } \\
\hline Watasenia scintillans & 5.3 & 889 & $21-57$ & 0.5 & 84 & $28-55$ & 5.8 & 973 \\
\hline Octopoteuthis sp. & - & - & - & 0.2 & 1 & 154 & 0.2 & 1 \\
\hline Histioteuthis spp. & - & - & - & 0.1 & 4 & $28-35$ & 0.1 & 4 \\
\hline Chiroteuthis sp. & - & - & - & 0.1 & 1 & 111 & 0.1 & 1 \\
\hline Abraliopsis sp. & - & - & - & $<0.1$ & 1 & 52 & $<0.1$ & 1 \\
\hline Total & 29.4 & 1068 & & 30.1 & 704 & & 59.4 & 1772 \\
\hline
\end{tabular}



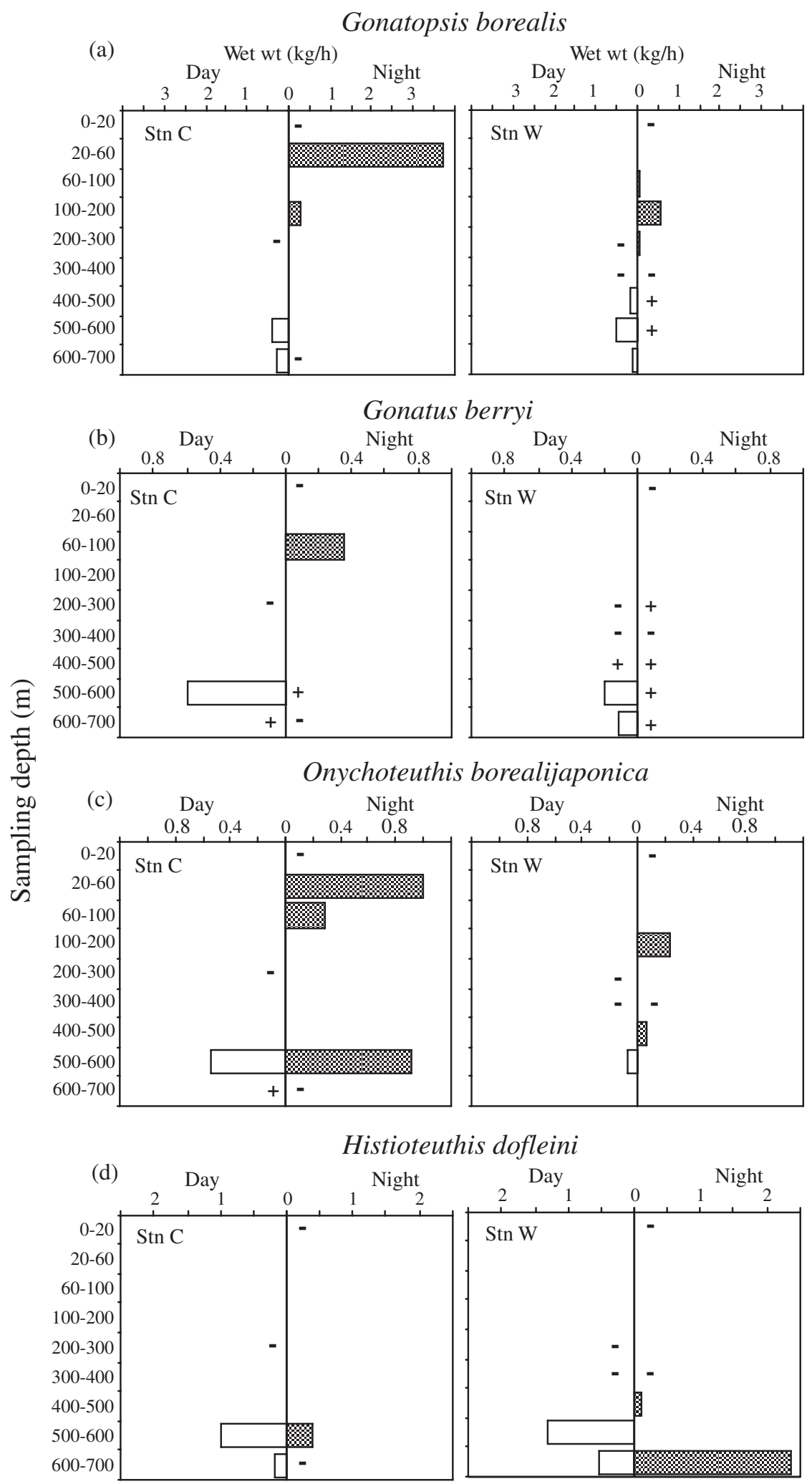

Fig. 3. Diel vertical migration patterns of (a) Gonatopsis borealis, (b) Gonatus berryi, (c) Onychoteuthis borealijaponica, and (d) Histioteuthis dofleini in the cold water mass (Stn C) and warm core ring (Stn W) in the transition region off Japan in July 1996. +: a catch of less than $0.05 \mathrm{~kg} \mathrm{~h}^{-1}$; -: a layer not sampled; blank indicates no catch
Onychoteuthis banksii. Vertical distribution: This species showed similar diel vertical migration patterns at Stns $\mathrm{C}$ and $\mathrm{W}$ : it migrated to the upper $100 \mathrm{~m}$ layer at night from a daytime habitat of between 400 and $700 \mathrm{~m}$ (Figs. 2 \& 4c).

Temperature range: From 3 to $6^{\circ} \mathrm{C}$ in the daytime and 5 to $20^{\circ} \mathrm{C}$ at night (eurythermal; Figs. 2 \& 4c).

\section{Slope water species}

Watasenia scintillans. Vertical distribution: This squid was mainly distributed in the 300 to $500 \mathrm{~m}$ layer during the daytime. At night its distribution shifted to the 20 to $60 \mathrm{~m}$ layer at Stn C and, apparently, the 60 to $100 \mathrm{~m}$ layer at Stn W, although far fewer captures were made at this station (Fig. 4d).

Temperature range: From 3 to $6^{\circ} \mathrm{C}$ during the day and 5 to $15^{\circ} \mathrm{C}$ at night (Figs. 2 \& 4d).

\section{Diel vertical migration of the less-abundant species}

Day and night distribution depths of the following 4 species (of which between 10 and 18 individuals were caught) are described below.

Gonatus onyx. At Stn C, this subarctic squid occurred in the 600 to $700 \mathrm{~m}$ layer in temperatures of 3 to $4{ }^{\circ} \mathrm{C}$ during the day, and migrated into the 20 to $100 \mathrm{~m}$ layer $\left(4\right.$ to $\left.6^{\circ} \mathrm{C}\right)$ at night. At Stn $\mathrm{W}$, catches were restricted to the 400 to $500 \mathrm{~m}$ layer $\left(5\right.$ to $6^{\circ} \mathrm{C}$ ) at night, probably because of warm waters in the upper layer.

Chiroteuthis calyx. This species was captured during the daytime at 600 to $700 \mathrm{~m}$ and 300 to $500 \mathrm{~m}$ at Stn $\mathrm{C}$ and Stn $\mathrm{W}$, respectively. The habitat temperature ranged from 3 to $7^{\circ} \mathrm{C}$.

Enoploteuthis chunii. This species was taken only from Stn W, in the 400 to $600 \mathrm{~m}$ layer $\left(4\right.$ to $6^{\circ} \mathrm{C}$ ) during the day and the 60 to $300 \mathrm{~m}$ layer (6 to $15^{\circ} \mathrm{C}$ ) at night.

Histioteuthis inermis. This species was recorded in the 500 to $700 \mathrm{~m}$ layer 

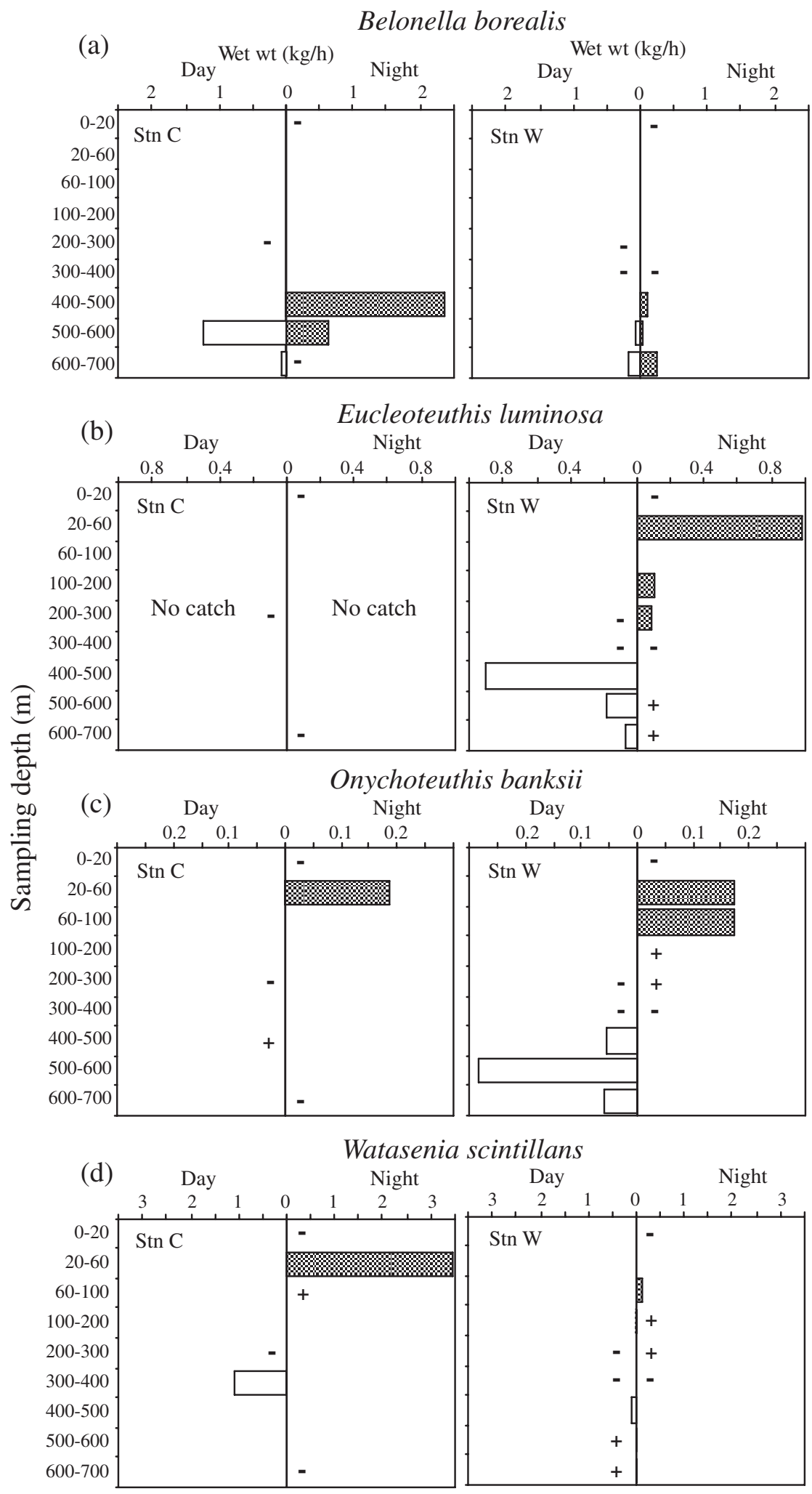

Fig. 4. Diel vertical migration patterns of (a) Belonella borealis, (b) Eucleoteuthis luminosa, (c) Onychoteuthis banksii, and (d) Watasenia scintillans in the cold water mass (Stn C) and warm core ring (Stn W) in the transition region off Japan in July 1996. +: a catch of less than $0.05 \mathrm{~kg} \mathrm{~h}^{-1}$; -: a layer not sampled; blank indicates no catch
(4 to $5^{\circ} \mathrm{C}$ ) during the day, and the 400 to $600 \mathrm{~m}$ layer $\left(4\right.$ to $\left.6^{\circ} \mathrm{C}\right)$ at night at Stn W, suggesting that this species is non-migrant and stenothermal.

\section{Difference in size distribution between CW and WCR areas}

The horizontal distribution patterns of juveniles, subadults, and adults in the transition region provides information on the geographical distribution of each species inside and outside of the transition region because the 2 sampling stations were in the Oyashio and Kuroshio-derived water masses. Among the most abundant 7 species taken at both sampling stations, the DML frequency distributions showed that juvenile Gonatopsis borealis (20 to $80 \mathrm{~mm}$ ), Gonatus berryi (20 to $80 \mathrm{~mm})$, Onychoteuthis borealijaponica (60 to $100 \mathrm{~mm}$ ), and Belonella borealis (160 to $240 \mathrm{~mm}$ ) were mainly distributed at Stn W, while larger subadults and adults (140-260, 100-160, 100-240, and 400-500 mm, respectively) were almost all restricted to Stn C (Fig. 5a-d). Most juvenile Histioteuthis dofleini (20 to $60 \mathrm{~mm}$ DML) and O. banksii (30 to $50 \mathrm{~mm}$ DML) were collected at Stn W, while their subadults and adults (60 to 160 and 50 to $80 \mathrm{~mm} \mathrm{DML,} \mathrm{respec-}$ tively) occurred at both stations (Fig. 5e,f). A near or total absence of juveniles of the above 6 species at Stn C suggests that their main spawning area is located in the southern transition region, or further south in the Kuroshio region, during winter and spring, and that their main nursery grounds are found in the southern transition region. Conversely, Watasenia scintillans showed similar unimodal size frequency distributions at both Stns C and W; its size range was 20 to $60 \mathrm{~mm}$ DML and its peak abundance was found between 40 and $50 \mathrm{~mm}$ DML (Fig. 5g), suggesting that this species spawns over a wide area in the transition region between the Oyashio and Kuroshio fronts as discussed later. 
(a) Gonatopsis borealis
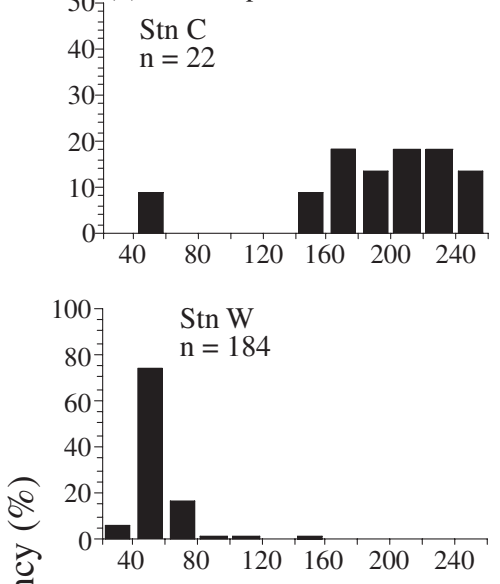

(e) Histioteuthis dofleini
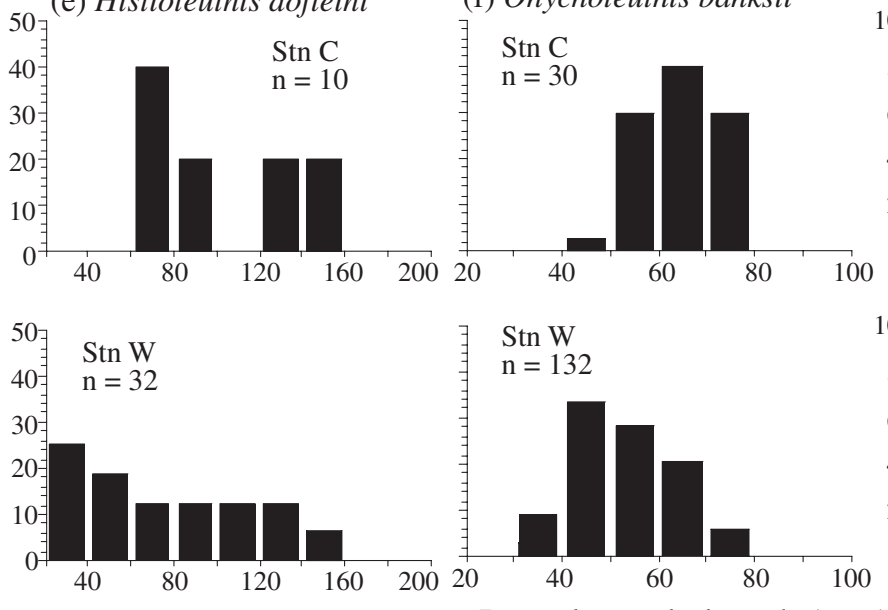

Dorsal mantle length $(\mathrm{mm})$
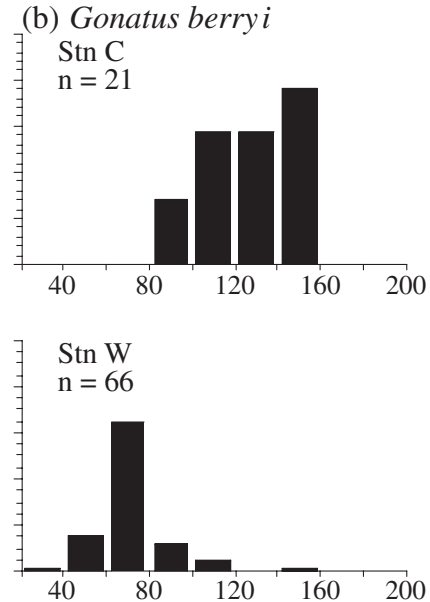

(f) Onychoteuthis banksii

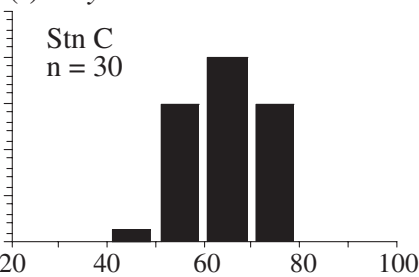

(c) Onychoteuthis boreali-

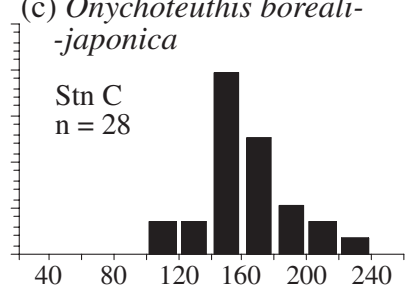

(d) Belonella borealis
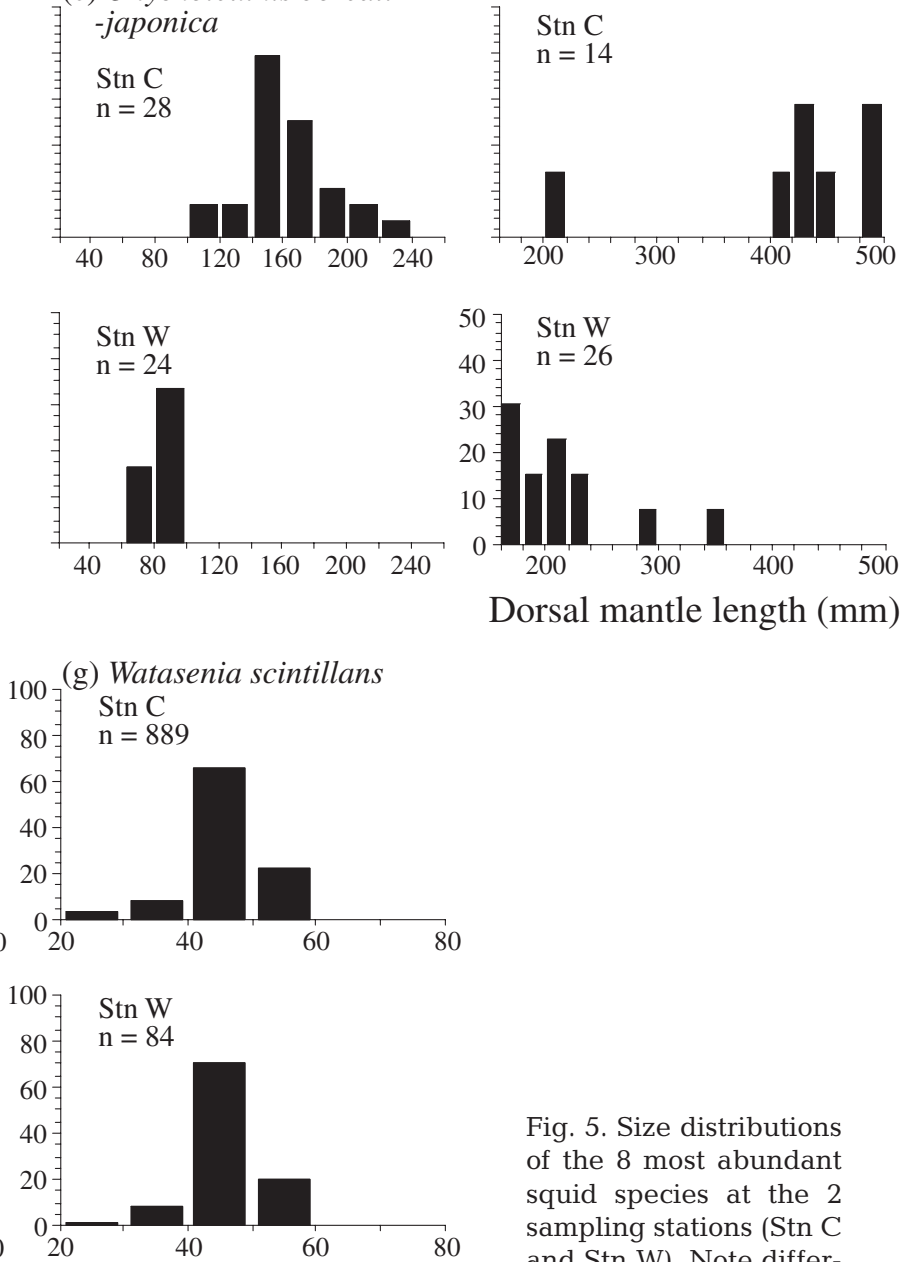

Fig. 5. Size distributions of the 8 most abundant squid species at the 2 sampling stations (Stn C and Stn W). Note different scales

\section{Vertical size distribution}

No significant difference in DML was observed between day and night habitats in any species (ANOVA, p > 0.05), indicating that no noticeable shift in body size with depth occurs for the species sampled in this study. Average sizes of Onychoteuthis borealijaponica, the semi-migrant that showed bimodal vertical distribution at night (Fig. 3c), were also similar for the meso- and epipelagic zone populations at the 2 sampling stations (Mann-Whitney $U$-test, p > 0.05).

\section{DISCUSSION}

\section{Sampling restrictions}

Some contamination is inevitable in deeper tows with open-trawl sampling. We estimated the amount of contamination by using the night catch data from deep tows for vertically migrant species. These were
Gonatopsis borealis, Gonatus berryi, Onychoteuthis banksii, and Watasenia scintillans at Stn C, and Eucleoteuthis luminosa, O. banksii, and W. scintillans at Stn W. Because almost all individuals of these species migrated to depths less than $100 \mathrm{~m}$ at night, their catch in deep tows can be regarded as the result of contamination from the upper 100 m layer (Figs. 3 \& 4). In the case of E. luminosa at Stn W at night, the catch in the 20 to $60 \mathrm{~m}$ layer was $0.98 \mathrm{~kg} \mathrm{~h}^{-1}$, and catches in the layers at 100-200, 200-300, 400-500, 500-600, and 600-700 m were 0.08, 0.07, 0, 0.04, and $0.04 \mathrm{~kg}$ $\mathrm{h}^{-1}$, respectively (Fig. $4 \mathrm{~b}$ ). Assuming that catches in the 5 deeper layers were contaminated by the 20 to $60 \mathrm{~m}$ layer, the contamination rate was calculated as 8.2, 7.1, $0,4.1$, and $4.1 \%(3.9 \pm 3.4 \%$, mean $\pm \mathrm{SD})$ of the 20 to $60 \mathrm{~m}$ layer catch, respectively. Based on the same procedure, mean contamination rates in the deeper tows for the other 4 species were calculated as $0.8 \pm 2.0 \%$ (range: 0 to $7.9 \%$ ). These results show that the contamination rates in tows deeper than $100 \mathrm{~m}$ were generally less than $4 \%$ of the total catch in the upper $100 \mathrm{~m}$. 


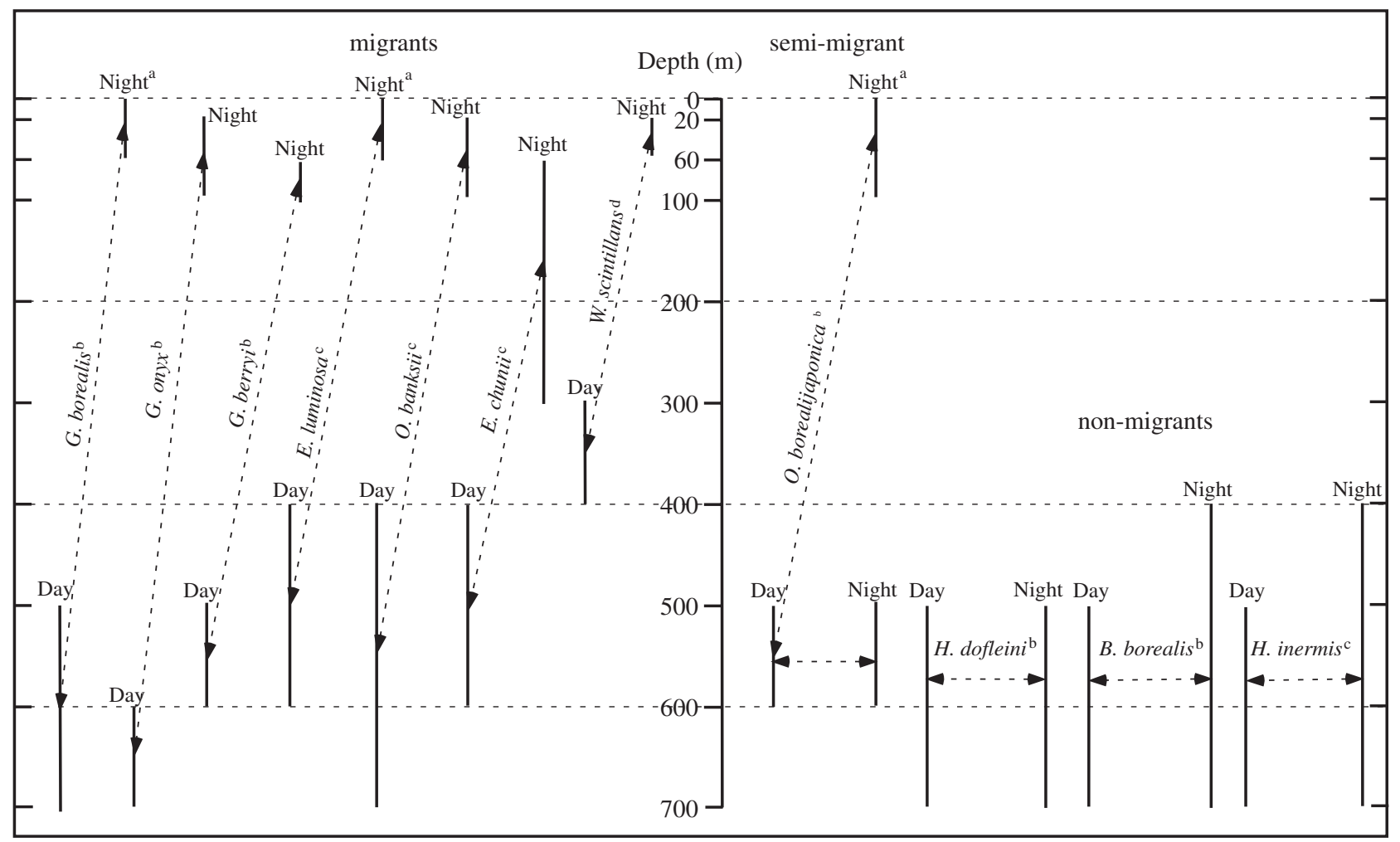

Fig. 6. Diel vertical migration patterns of: 6 subarctic and transition water species in the CW area; 4 subtropical species in the WCR area; and 1 slope water species in both areas. The layers in which more than $80 \%$ of the total catch was recorded are defined as the habitat depth. ${ }^{a}$ Migrate into the 0 to $7 \mathrm{~m}$ layer at night (Naito et al. 1977, Pearcy et al. 1996, Ishida et al. 1999);

${ }^{b}$ subarctic and transition water species; ${ }^{c}$ subtropical species; ${ }^{d}$ slope water species. Full species names are given in Table 1

Data on the DVM patterns and habitat temperature ranges of species that migrate above $20 \mathrm{~m}$ at night were not obtained in this study. However, this deficit can be supplemented by citing the results of extensive surface gillnet sampling in the western North Pacific (Naito et al. 1977, Pearcy et al. 1996, Ishida et al. 1999).

\section{DVM patterns}

Night sampling by surface gillnet indicates that Gonatopsis borealis and Onychoteuthis borealijaponica migrate up to the 0 to $7 \mathrm{~m}$ layer where the sea surface water temperature (SST) is 5 to $11^{\circ} \mathrm{C}$ and 6 to $14^{\circ} \mathrm{C}$, for each species respectively (Naito et al. 1977, Ishida et al. 1999). Eucleoteuthis luminosa is also known to occur in the surface layer at night when the SST is higher than $14^{\circ} \mathrm{C}$ in the southern transition region (Pearcy et al. 1996, H. Watanabe unpubl. data). Stn C and Stn W were strongly affected by Oyashio and Kuroshio-derived waters, respectively. Therefore, the subarctic and transition water species, and the subtropical species, are thought to show normal DVM patterns at Stn C and Stn W, respectively. The vertical distribution patterns of deep-dwelling non-migrant species did not differ between the 2 sampling stations, probably because their habitats are not affected by the upper-layer warm waters of the WCR. Based on the present data, together with previous gillnet sampling data, the DVM patterns of the most common 11 squid species can be categorized into the following 3 types (Fig. 6):

(1) Migrants, in which day and night habitats are clearly separated: G. borealis, Gonatus berryi, Gonatus onyx, E. luminosa, Onychoteuthis banksii, Enoploteuthis chunii, and Watasenia scintillans;

(2) Semi-migrant, in which part of the population remains in the daytime habitat at night. The depth distributions of migratory and non-migratory populations do not overlap: $O$. borealijaponica;

(3) Non-migrants: Histioteuthis dofleini, Belonella borealis, and $H$. inermis.

DVMs of squid are regarded as feeding migrations into the upper productive layer, not only for zooplankton feeders, but also for micronekton and nekton feeders. This is because at night, smaller micronektonic prey, such as myctophid fishes and Watasenia scintillans, migrate into the epipelagic zone from the mesopelagic, and small, abundant epipelagic prey, such as sardine, anchovy, and saury, are also vulnera- 
ble to predation at night (Shimizu \& Nihira 1989, Tsuruta \& Takahashi 1997, Watanabe et al. 1999, this study). Migratory squid require more energy than nonmigratory species because squid have no buoyancy control organs and their metabolic rate is higher in the high-temperature epipelagic zone. At night, this preyrich environment is likely to assure enough energy to compensate for active vertical migration. Conversely, non-migratory species adopt an energy-saving feeding strategy, and have gelatinous bodies and poor swimming abilities. Among the non-migrants, Histioteuthis dofleini and $H$. inermis have small vacuoles in the muscles of their mantle and arms filled with low density fluid containing ammonium (Clarke et al. 1969). Belonella borealis has coelomic fluid containing ammonium that occupies 60 to $70 \%$ of its body volume (Denton \& Gilpin-Brown 1973). These vacuoles and coelomic fluids are suggested to aid in low-energy maintenance of neutral buoyancy in non-migrant squid in the mesopelagic zone (Clarke et al. 1969, Denton \& Gilpin-Brown 1973). The semi-migrant Onychoteuthis borealijaponica may have a flexible feeding strategy, or one that is intermediate between migratory and non-migratory species. Individuals that feed enough in a preceding night, or during the day, may skip a DVM to save energy. This feeding strategy is known to occur in the micronektonic myctophid fish Stenobrachius leucopsarus in the transitional and subarctic North Pacific (Paxton 1967, Pearcy et al. 1977, Watanabe et al. 1999). Semi-migrant squid and fish are widely distributed in transition and subarctic waters where the prey-rich environment extends to the mesopelagic zone, enabling possible daytime feeding in this zone.

\section{Habitat temperature}

Day-night habitat temperature ranges of the 11 species based on the present results together with those of surface gillnet sampling (Naito et al. 1977, Pearcy et al. 1996, Ishida et al. 1999) are summarized in Fig. 7. Migrants are generally eurythermal, and temperature differences between day and night habitats are 7 to $17^{\circ} \mathrm{C}$. One exception was observed in the typical subarctic species Gonatus onyx, which is stenothermal and restricted to waters at 3 to $4^{\circ} \mathrm{C}$ in the day and 4 to $6^{\circ} \mathrm{C}$ at night. Among the vertical migrants, subtropical species and slope water species are generally more eurythermal than subarctic and transition water species. All non-migrants are stenothermal and their habitat temperature range is between 3 and $6^{\circ} \mathrm{C}$.

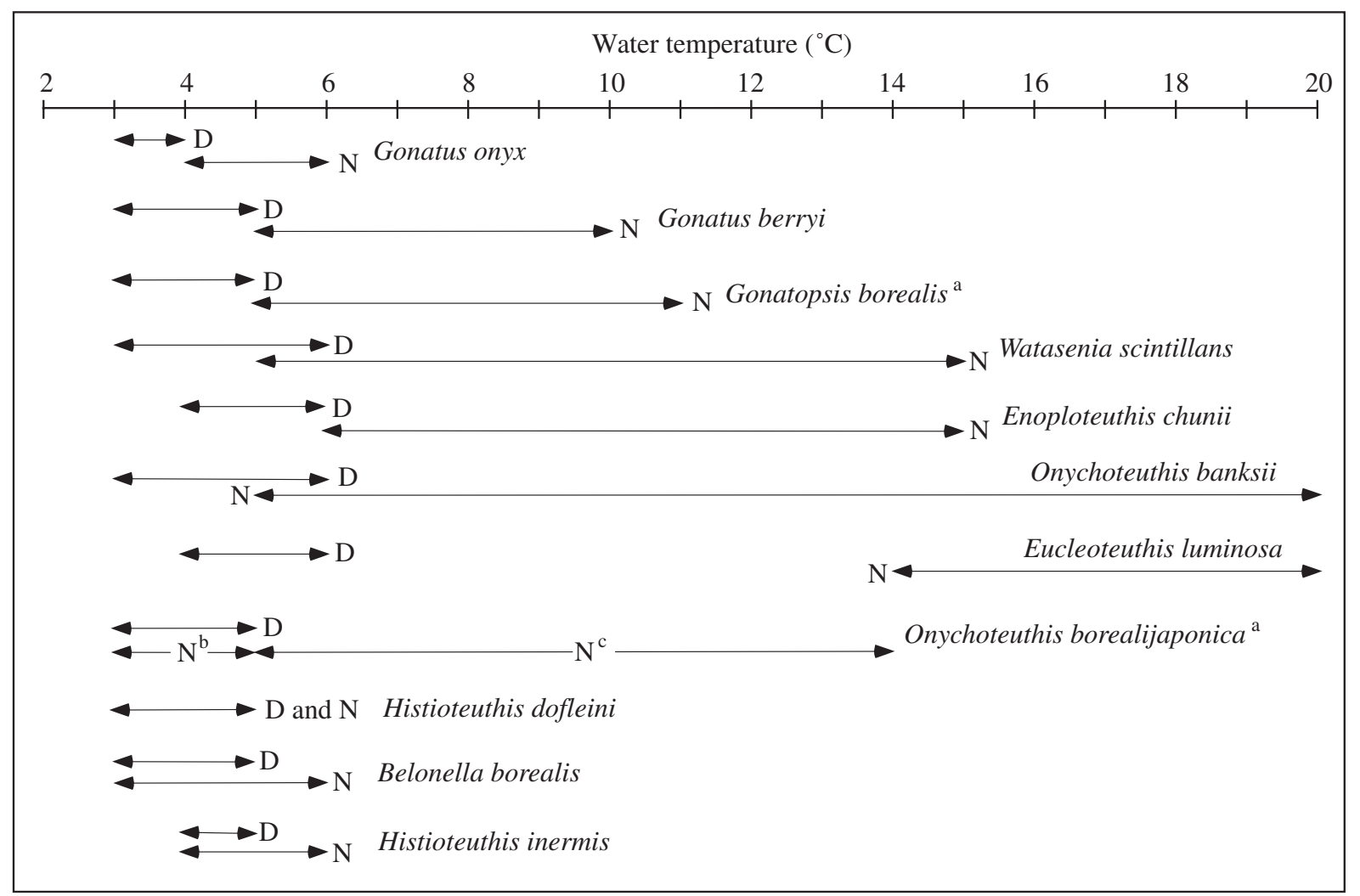

Fig. 7. Day (D) and night (N) habitat temperature ranges of the 11 squid species. ${ }^{\text {a }}$ The highest SST data are cited from Naito et al. (1977) and Ishida et al. (1999); ${ }^{b}$ non-migratory population; ${ }^{c}$ migratory population 


\section{Zoogeographical distribution}

Onychoteuthis borealijaponica is thought to use the southern warm transition waters as both spawning and nursery grounds because it undergoes migration from the subarctic to the southern transition region in autumn before spawning occurs in winter and spring (Young 1972, Naito et al. 1977, Kubodera et al. 1983). The restricted distribution of juveniles to the WCR supports this view.

Most juveniles of Gonatopsis borealis, Gonatus berryi, Belonella borealis, Histioteuthis dofleini, and Onychoteuthis banksii were also distributed in the WCR. This indicates that their spawning and/or nursery grounds are in the southern transition region and/or further south in the Kuroshio region during winter and spring, since there is no notable southward current in their larval habitat, i.e. the epipelagic zone in the transition region (Uda 1970). Therefore, the southern transition region would function as spawning and/or nursery grounds for various squid, including subarctic and transition water species and subtropical species. The importance of the southern transition region south of the subarctic boundary has been pointed out for various mesopelagic fish species, such as myctophids Symbolophorus californiensis and Diaphus theta, and the melanostomiid Tactostoma macropus (Fisher \& Pearcy 1983, Kawaguchi \& Moser 1993, Sassa et al. 2002, Moku et al. 2003). However, in the case of Watasenia scintillans, which is common in Japanese slope and shelf-edge waters (Tsuchiya 2000), juvenile and adult populations were mixed in the both $\mathrm{CW}$ and WCR areas. This probably reflects the fact that these squid use the entire transition region off Japan as spawning and/or nursery grounds. The occurrence of slope water species in the offshore area of the transition region has also been reported for the micronektonic sternoptychid fish Maurolicus japonicus (Sassa et al. 2002). This distribution pattern may be closely related to the separation of water masses from Japanese slope waters, including Tsugaru warm waters from the Japan Sea, through complicated hydrographic interactions between the Oyashio and Kuroshio Currents.

Acknowledgements. We gratefully acknowledge the late A. Ohno, the former chief investigator of the Japan Marine Fishery Resources Research Center, for his kind help during the cruise. We are also grateful to Captain S. Akita, Fishing Master T. Hayashi, and the crew of the commercial trawler 'Marusada-Maru' for their skillful assistance in the field sampling. Drs T. Ichii of the National Research Institute of Far Seas Fisheries, K. Phillips of the Japan Society for the Promotion of Science, and $\mathrm{K}$ Mori of the Hokkaido National Fisheries Research Institute gave valuable advice and comments during the course of this study. This research was supported by a grant from Marino Forum 21 and the Japanese Fisheries Agency.

\section{LITERATURE CITED}

Clarke MR (1966) A review of the systematics and ecology of oceanic squids. Adv Mar Biol 4:91-300

Clarke MR, Denton EJ, Gilpin-Brown JB (1969) On the buoyancy of squid of the families Histioteuthidae, Octopoteuthidae and Chiroteuthidae. J Physiol Lond 203:49-50

Denton EJ, Gilpin-Brown JB (1973) Floatation mechanisms in modern and fossil cephalopods. Adv Mar Biol 11:197-268

Fisher JP, Pearcy WG (1983) Reproduction, growth and feeding of the mestopelagic fish Tactostoma macropus (Melanostomiatidae). Mar Biol 74:257-267

Iizuka S (1990) Consideration of swimming ecology and formation of fishing ground for diamondback squid Thysanoteuthis rhombus. Report of the annual meeting of study on squid resource and fishing condition. Tohoku Natl Fish Res Inst 63-69 (in Japanese)

Ishida Y, Azumaya T, Fukuwaka M (1999) Summer distribution of fishes and squids caught by surface gillnets in the western North Pacific Ocean. Bull Hokkaido Natl Fish Res Inst 63:1-18

Kawaguchi K, Moser HG (1993) Development and distribution of the early life history stages of the mesopelagic fish Tactostoma macropus (Stomiidae) in the transitional waters of the North Pacific. Jpn J Ichthyol 40:161-172

Kawai H (1972) Hydrography of the Kuroshio and the Oyashio. In: Iwashita M, Komaki Y, Hoshino T, Horibe S, Masuzawa J (eds) Physical oceanography II, Kaiyogaku Kiso Koza (Fundamental lectures of oceanography). Tokai University Press, Tokyo, p 129-320 (in Japanese)

Kubodera T, Pearcy WG, Murakami K, Kobayashi T, Nakata J, Mishima S (1983) Distribution and abundance of squids caught in surface gillnets in the subarctic Pacific, 1977-1981. Mem Fac Fish Hokkaido Univ 30:1-49

Moku M, Tsuda A, Kawaguchi K (2003) Spawning season and migration of the myctophid fish Diaphus theta in the western North Pacific. Ichthyol Res 50:52-58

Mori J, Kubodera T, Baba N (2001) Squid in the diet of northern fur seals, Callorhinus ursinus, caught in the western and central North Pacific Ocean. Fish Res 52:91-97

Naito M, Murakami K, Kobayashi T, Nakayama N, Ogasawara J (1977) Distribution and migration of oceanic squids (Ommastrephes bartramii, Onychoteuthis borealijaponica, Berryteuthis magister and Gonatopsis borealis) in the western subarctic Pacific region. Spec Vol Res Inst North Pac Fish Hokkaido Univ Fac Fish 321-337 (in Japanese with English abstract)

Nakamura Y (1991) Tracking of the mature female of flying squid, Ommastrephes bartramii, by an ultrasonic transmitter. Bull Hokkaido Natl Fish Res Inst 55:205-208

Nesis KN (1982) Caphalopods of the world. Copyright Agency of the USSR for Light and Food Industry Publishing House, Moscow, TFH Publications, for the English translation

Ohizumi H, Kuramochi T, Amano M, Miyazaki N (2000) Prey switching of Dall's porpoise Phocoenoides dalli with population decline of Japanese pilchard Sardinops melanostictus around Hokkaido, Japan. Mar Ecol Prog Ser 200: 265-275

Ohizumi H, Isoda T, Kishiro T, Kato H (2003) Feeding habits of Baird's beaked whale Berardius bairdii, in the western North Pacific and Sea of Okhotsk off Japan. Fish Sci 69: $11-20$

Okutani T (2002) Taxonomy and distribution of squids. In: Nasu K, Okutani T, Ogura M (eds) The squid. Seizando Press, Tokyo, p 1-33 (in Japanese)

Okutani T (2005) Cuttlefishes and squids of the world. Publication for the 40th anniversary of the foundation of 
national cooperative association of squid processors. Okumura Printing Co, Tokyo (in Japanese)

Okutani T, Satake Y, Ohsumi S, Kawakami T (1976) Squids eaten by sperm whales caught off Joban district, Japan, during January-February, 1976. Bull Tokai Reg Fish Res Lab 87:67-113

Paxton JR (1967) A distributional analysis for the lanternfishes (family Myctophidae) of the San Pedro Basin, California. Copeia 2:422-440

Pearcy WG (1991) Biology of the transition region. NOAA Tech Rep NMFS 105:39-55

Pearcy WG, Krygier EE, Mesecar R, Ramsey F (1977) Vertical distribution and migration of oceanic micronekton off Oregon. Deep-Sea Res 24:223-245

Pearcy WG, Fisher JP, Anma G, Meguro T (1996) Species associations of epipelagic nekton of the North Pacific Ocean, 1978-1993. Fish Oceanogr 5:1-20

Roper CFE, Young RE (1975) Vertical distribution of pelagic cephalopods. Smithson Contrib Zool 209:1-51

Sassa C, Kawaguchi K, Kinoshita T, Watanabe C (2002) Assemblages of vertical migratory mesopelagic fish in the transitional region of the western North Pacific. Fish Oceanogr 11:193-204

Shimizu N, Nihira A (1989) Distribution of pelagic fishes and oceanic fronts in the northwestern Pacific Ocean. Bull Ibaragi Pref Fish Res Inst 26:113-126 (in Japanese with English abstract)

Sweeney MJ, Roper CFE, Mangold KM, Clarke MR, Boletzky SV (1992) 'Larval' and juvenile cephalopods: a manual for their identification. Smithson Contrib Zool 513:1-282

Tanaka H (2001) Tracking the neon flying squid by the biotelemetry system in the central North Pacific Ocean. Aquabiology. Seibutsu Kenkyusha Press, Tokyo, 137: 533-539 (in Japanese with English abstract)

Editorial responsibility: Howard I. Browman (Associate Editor-in-Chief), Storebø, Norway
Tsuchiya K (2000) Illustrated book of the Enoploteuthidae. In: Okutani $\mathrm{T}$ (ed) True face of Watasenia scintillans. Tokai University Press, Tokyo, p 196-269 (in Japanese)

Tsuruta Y, Takahashi S (1997) Reproductive ecology of the Japanese anchovy (Engraulis japonicus H.) in the Kuroshio extension and the mixed water region. Bull Hokkaido Natl Fish Res Inst 61:9-15

Uda M (1970) Fishery oceanographic studies of frontal eddies and transport associated with the Kuroshio system including the 'Subtropical Countercurrent'. In: Marr JC (ed) The Kuroshio. East-West Center Press, Honolulu, HI, p 593-604

Voss NA, Nesis KN, Rodhouse PG (1998) The cephalopod family Histioteuthidae (Oegopsida): systematics, biology, and biogeography. In: Voss NA, Vecchione M, Toll RB, Sweeney MJ (eds) Systematics and biogeography of cephalopods, Vol II. Smithson Contrib Zool 586:293-372

Watanabe H, Moku M, Kawaguchi K, Ishimaru K, Ohno A (1999) Diel vertical migration of myctophid fishes (family Myctophidae) in the transitional waters of the western North Pacific. Fish Oceanogr 8:115-127

Watanabe H, Kubodera T, Kawahara S (2003) Feeding habits of Pacific pomfret Brama japonica in the transition zone of the central North Pacific. Fish Sci 69:269-276

Watanabe H, Kubodera T, Ichii T, Kawahara S (2004a) Feeding habits of neon flying squid Ommastrephes bartramii in the transitional region of the central North Pacific. Mar Ecol Prog Ser 266:173-184

Watanabe H, Kubodera T, Masuda S, Kawahara S (2004b) Feeding habits of albacore Thunnus alalunga in the transition region of the central North Pacific. Fish Sci 70: 573-579

Young RE (1972) The systematics and areal distribution of pelagic cephalopods from the seas off southern California. Smithson Contrib Zool 97:1-159

Submitted: June 3, 2005; Accepted: November 23, 2005 Proofs received from author(s): May 23, 2006 